\title{
Bibliometric Analysis of International Vocational Education Studies
}

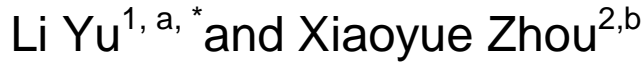 \\ ${ }^{1}$ Changchun Automobile Industry Institute, Changchun P. R. China \\ ${ }^{2}$ School of Management Jilin University, Changchun P. R. China \\ aperfectamy21st@126.com, ${ }^{b}$ markruby@sina.com
}

Keywords: Vocational education; Knowledge mapping; Bibliometrics; SSCI

\begin{abstract}
Based on 719 papers on vocational education indexed by SSCI and knowledge mapping software Cite Space, the paper provide a summary description of international VE studies. The conclusion demonstrates that the academic impact of European countries and USA take the dominant positions. The internationalization of China's VE studies need be strengthened. Five knowledge group are derived from the knowledge mapping.
\end{abstract}

\section{Introduction}

Vocational education plays an important role in the process of national industrialization, which can not be replaced by other types of education. In Germany, for example, the country's manufactured products are known as excellent performance and quality. This is not only because the Germans have a rigorous attitude toward work, also have big relationship with Germans attaching great importance to vocational education[1]. Vocational education is considered to be the foundation of the German "economic take-off wings" and "the foundation of national survival". 30 years of reform and opening up, the development of Vocational Education in China, the number of institutions, the size and the quality of teaching have made very brilliant achievements. However, compared with Europe and the United States and other developed countries, China's professional education still has shortcomings, such as inadequate investment, unbalanced development, and the connection between vocational qualification certificate and vocational school diploma is not enough. To solve these shortcomings, we need to learn from the advanced experience of developed countries such as Europe and the United States. Compared with the developed countries such as Europe and the United States, there are great differences between the development of vocational education pattern and the research paradigm. This paper base on the view of literature metrology of international vocational education academic to analyze the statistics of relevant papers, in order to reveal nearly 10 years the main research content and research paradigm of the international vocational education, so as to achieve a benefit of academic study in Higher Vocational Education in our country.

\section{Data and Methods}

The research data is from Social science/index database of Thomson Reuters technology company(hereinafter referred to as SSCI). Through the theme of "Vocational Education", I have totally retrieve 719 data of relevant professional education from 2000-2009. Document types are limited to research papers, conference papers and review papers. The data retrieval formulation follows:

Topic $=($ Vocational* same Education*) AND Year Published=(2000-2009) And Document Type $=($ Article or Proceeding Paper or Review $)$ Time span=All years. Databases $=$ SSCI

In addition to the traditional methods of document measurement, this paper also uses the visual analysis software Cite Space, to draw a knowledge map of the literature and cited (Co-Citation) knowledge for the international vocational education research. The drawing principle of knowledge map is as follows: firstly, starting at a paper's reference, build the same cited matrix of the reference; then, the paper uses the vector algorithm to cluster the file; after that, according to the cluster 
rendering document co citation network, we can find the larger cluster in the network is known as knowledge group; finally, use the Citing paper of the reference implementation of Cited Literature can provide title, keywords, abstract information, and extract the research content from knowledge group based on text mining algorithm. Knowledge map is the latest research on bibliometric method [2]. It converts the vast amount of literature data in the field of science into visual image, displays the overall picture, development trend and structure characteristics of the subjects that are difficult to be directly obtained by personal experience.

\section{Analysis and Results}

The General Situation of Academic Research in the Field of International Logistics. International papers on vocational education has increased year by year[4]. In 2000, there were only 53 papers on the topic of Vocational Education in the world. In 2009, there were 121 papers have published around the world. Within 10 years, it has increased nearly double times. It also shows some related research on the international vocational education gradually increase.

719 papers distribute on almost 364 journals, involving a number of overlapping disciplines, such as, 252 papers about education, 61 papers about psychology, 53 papers about sociology (53), 44 papers about economics, 39 papers about psychiatry, 25 papers about management, politics and labor relations. The distribution of this kind of subject indicates that the research of vocational education is a complex system, which the foundation is education, related to so many other subjects. I have collected the amount of published the vocational education papers, and found that there are 20 countries (Table 1). It shows that in Table 1 there are two countries that are the United States and the United Kingdom, whose output of the paper about the vocational education research is highest, followed by Germany and Australia. SSCI was first developed by the Institute of scientific information in Philadelphia (ISI), in order to recruit English Journals. As a result, the elimination of native English speaking countries, and considering the national scale factors, the countries about the Nordic (Finland, Denmark, Sweden and Norway) and Western Europe (Holland and Belgium) countries have paid more attention to vocational education[5]. In Asia, the mainland and Taiwan have paid more attention to vocational education. However, comparing with Europe and North America, the output of paper is less. It is remarkable that Japanese vocational education is most successful countries in Asia[3], but the international paper about vocational education in this country is 0 .

Table 1 Published the international vocational papers among 20 countries

\begin{tabular}{|l|l|l|l|}
\hline Region & $\begin{array}{c}\text { Number of } \\
\text { papers }\end{array}$ & Region & Number of papers \\
\hline America & 212 & Sweden & 14 \\
\hline British & 112 & Turkey & 13 \\
\hline German & 71 & Belgium & 12 \\
\hline Australia & 62 & China & 11 \\
\hline Holland & 58 & Spain & 10 \\
\hline Finland & 30 & Taiwan & 9 \\
\hline Switzerland & 23 & Italy & 8 \\
\hline Canada & 22 & South Africa & 8 \\
\hline Switzerland & 17 & Norway & 7 \\
\hline French & 16 & Poland & 7 \\
\hline
\end{tabular}

Research Content. The author use the software of Cite Space have got some information following Fig. 1 which formed CO citation map knowledge based on 719 papers drawn references, 
which have got 29249 references were divided into 5 groups according to the cited year. Each group selected the highest citation frequency of 30 references, and finally formed a network of 127 nodes and 344 edges. After clustering, there were five large knowledge clusters, each of which is composed of a number of smaller reference documents clustering. The cluster label of Fig. 1 is based on the key words in the citation literature. Through the $\mathrm{tf}^{*} \mathrm{idf}$ algorithm, we also referred to the text mining results of Log-Likelihood ration and mutual information in the concrete analysis. The high cited references and cluster labels reflect the main content of the knowledge group[6].

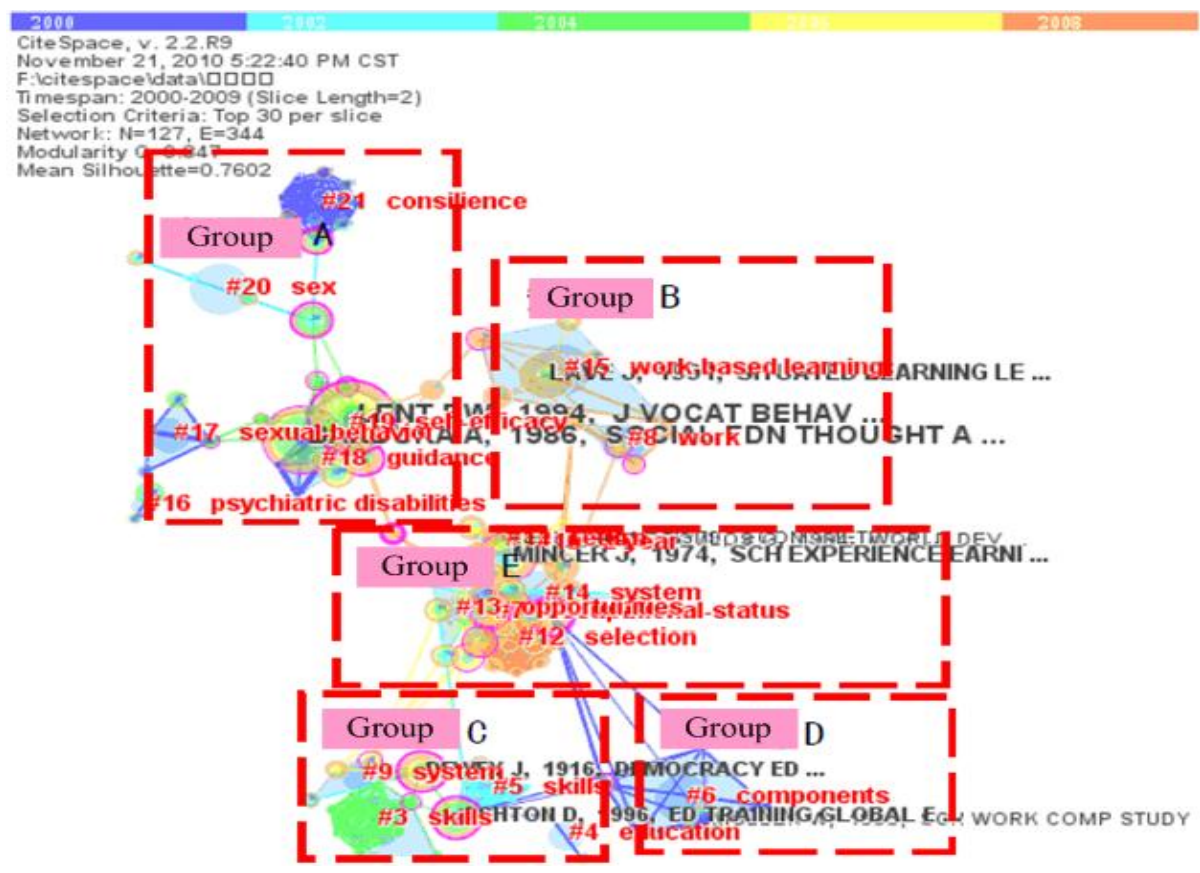

Figure 1. SSCI papers of vocational education and the knowledge map of the cited cluster

(1) Knowledge group A: Social psychology research on Vocational Education

Knowledge group A is mainly related to the interaction between vocational education and society (Table 2). Specifically, it includes the choice of the professional education of social cognition, and the purpose to vocational education and social expectations, and Performance differences of male and female students in vocational education, and adolescent psychological counseling of vocational education school [7].

Table 2 High cited references of knowledge group A and the main clustering label vocabulary

\begin{tabular}{|c|c|}
\hline Part of High cited references & $\begin{array}{c}\text { cluster label } \\
\text { vocabulary }\end{array}$ \\
\hline $\begin{array}{l}\text { Lent Robert W, Brown Steven D. Toward a unifying social cognitive } \\
\text { theory of career and academic interest, choice, and performance[J]. Journal } \\
\text { of vocational behavior, 1994, 45(1): 79-122. }\end{array}$ & $\begin{array}{c}\text { sexual-behavior, } \\
\text { research criteria, } \\
\text { guidance, self-efficacy, } \\
\text { career development, } \\
\text { experience ,adolescent, } \\
\text { Lent R W, Brown S D, Hackett G. Contextual Supports and Barriers to } \\
\text { Career Choice: A social Cognitive Analysis *1[J]. Journal of Counseling } \\
\text { Psychology, 2000, 47(1):36-49. }\end{array}$ \\
$\begin{array}{c}\text { Dawis R V, Lofquist L H. A psychological theory of work } \\
\text { adjustment[M].Univ. of Minnesota Press, 1984 }\end{array}$
\end{tabular}

(2)Knowledge group B: the relationship between vocational education and economics development

Knowledge group B is mainly focus on adaptability problem between vocational education and economics development(Table 3). These problems mainly include(1)the influence between economics development and invest of vocational education;(2)the relationship between the cost of 
human resource and training cost of career technical college;(3) the mutual influence between trade union organization and vocational education;(4) vocational education how to adjust to development of future knowledge economy [8].

Table 3 Highly cited references of knowledge group B and the main clustering label vocabulary

\begin{tabular}{|c|c|}
\hline Part of High cited references & $\begin{array}{l}\text { cluster label } \\
\text { vocabulary }\end{array}$ \\
\hline $\begin{array}{c}\text { Biemans H, Nieuwenhuis L, Poell R, et al. Competence-based VET in the } \\
\text { Netherlands: background and pitfalls[J]. Journal of vocational education \& } \\
\text { Training, 2004, 56(4): 523-538. }\end{array}$ & \multirow{3}{*}{$\begin{array}{l}\text { trade union, work, } \\
\text { education, work-based } \\
\text { learning, expert, } \\
\text { knowledge, networks } \\
\text { between schools and } \\
\text { businesses, } \\
\text { workplace }\end{array}$} \\
\hline $\begin{array}{l}\text { Becker G S. Human capital: A theoretical and empirical analysis, with } \\
\text { special references to education[M].University of Chicago press, } 1993 \text {. }\end{array}$ & \\
\hline $\begin{array}{l}\text { Giddens A. Modernity and self-identify: Self and society in the late } \\
\text { modern age[M]. Stanford Univ Press, } 1991\end{array}$ & \\
\hline
\end{tabular}

(3)Knowledge group C: Research on Lifelong vocational education

The discussion theme of knowledge group $\mathrm{C}$ is lifelong vocational education (Table 4), for instance, the purpose of lifelong vocational education; some notes for teaching and training of vocational education; case study from European and American countries.

Table 4 Highly cited references of knowledge group $\mathrm{C}$ and the main clustering label vocabulary

\begin{tabular}{|c|c|}
\hline Part of High cited references & $\begin{array}{c}\text { cluster label } \\
\text { vocabulary }\end{array}$ \\
\hline $\begin{array}{c}\text { Brown J S, Collins A, Duguid P. Situated cognition and the culture of } \\
\text { learning [J]. Educational researcher, 1989, 18(1):32-42. }\end{array}$ & $\begin{array}{c}\text { skill, life course, } \\
\text { school, career and } \\
\text { technical education, } \\
\text { system, student } \\
\text { achievement } \\
\text { Forkplace: creating and managing expansive and restrictive participation } \\
\text { [J].Journal of education and work, 2003, 16(4): 407-426. }\end{array}$ \\
\hline $\begin{array}{c}\text { Dewey J. Democracy and education[M].New York: Macmillan, Inc., } \\
1996\end{array}$ & \\
\hline
\end{tabular}

(4)Knowledge group D: the policy of vocational education

The discussion theme of knowledge group $\mathrm{D}$ is the significant development of vocational education (Table 5).For example, the development of vocational education is helpful to the stability of the employment market, especially in the period of economic depression.

Table 5 High cited references of knowledge group D and the main clustering label vocabulary

\begin{tabular}{|c|c|}
\hline High cited references & $\begin{array}{l}\text { cluster label } \\
\text { vocabulary }\end{array}$ \\
\hline $\begin{array}{l}\text { Block F L. Postindustrial possibilities: A critique of economic } \\
\text { discourage [M]. Univ of California Pr, } 1990 .\end{array}$ & \multirow{3}{*}{$\begin{array}{l}\text { Technical-vocational } \\
\text { education, attainment, } \\
\text { career development, } \\
\text { supported development }\end{array}$} \\
\hline $\begin{array}{c}\text { Shavit Y, Muller W, Tame C. From school to work: a comparative } \\
\text { study of educational qualifications and occupational destinations [M]. } \\
\text { Oxford University Press, USA, } 1998 \text {. }\end{array}$ & \\
\hline $\begin{array}{l}\text { Maurice M, Sellier F, Silverstre J J. The social foundations of industrial } \\
\text { power: A comparison of France and Germany [M].The MIT Press, } 1986 .\end{array}$ & \\
\hline
\end{tabular}

(5)Knowledge group E: Analysis model of Vocational Education

Compared with knowledge group A, B, C, D, the literature of knowledge group $\mathrm{E}$ is emphasis on mathematical statistics and empirical case analysis. Allmedinger has analyzed the vocational educational system of the United States, Norway and West Germany, and then divided into two different models: standardization, that is, vocational schools provide the training for students in accordance with the unified standard; Hierarchy, Customized training for students according to the 
different market. Although the two models are different from each other, they can transform into each other[9]. Breen has proposed a new molder in his paper, which provide a functional relation between vocational education on stratification and employment. From high cited frequency references and citing articles, hierarchical vocational education is the current focus of the quantitative study [10].

Table 6 High cited references of knowledge group E and the main clustering label vocabulary

\begin{tabular}{|c|c|}
\hline High cited references & $\begin{array}{c}\text { cluster label } \\
\text { vocabulary }\end{array}$ \\
\hline $\begin{array}{c}\text { Breen R, Jonsson J O. Analyzing educational careers: A multinomial } \\
\text { transition model[J]. American Sociological Review, 2000, 65(5): 754-772. }\end{array}$ & $\begin{array}{c}\text { Occupational-status, } \\
\text { developing countries, } \\
\text { Selection, } \\
\text { Allmedinger J. Educational systems and labor market outcomes[J]. } \\
\text { European Sociological Review, 1989, 5(3): 231. }\end{array}$ \\
\begin{tabular}{c|c} 
opportunities, \\
participation, transition, \\
Aman J S. Social capital in the creation of human capital[J].
\end{tabular} \\
\hline
\end{tabular}

\section{Conclusion and Discussion}

This paper is based on the sample of 719 vocational education papers of SSCI, which use the method of literature measurement, including the knowledge map, to investigate the situation of international vocational education. We can get some conclusions:

The research of vocational education is a whole system, which takes the education as the main body, and permeates, intersect and reconcile with other subjects. Besides, vocational education research in Europe and the United States has obvious advantages against other countries among the international academic domain, and the national study of Vocational Education in China needs to pay more attention to this field. Finally, the research on vocational education can be divided into five main sub areas and they are social psychology research on vocational education, the relationship between vocational education and economics development and Research on Lifelong vocational education.

\section{Acknowledgements}

The authors would like to thank Advisory Committee of Foreign Language Teaching in Vocational Education, Ministry of Education of P. R. China under the grant of GZGZ5414-82.

\section{References}

[1] Tong L. Vocational Education - the German economy to take off the wings. China Modern Educational Equipment,2 (2005)62-65.

[2] Chen B., Yi W. Research on the metrological analysis of Higher Vocational Education in China the 30 years of reform and opening up. Education and Vocation, 32(2008) 5-8.

[3] Fu J., Sun B. Development trend of Vocational Education in foreign countries. Journal of Henan Vocation-Technical Teachers College (Vocational Education Edition), 5(2005)51-54.

[4] Chen C. Cite Space II: Detecting and visualizing emerging trends and transient patterns in scientific literature. Journal of the American Society for Information Science and Technology, 57(2006)359-377.

[5] Chen Y., Ze L. The rise of scientific knowledge map. Studies in Science of Science, 23(2005)149-154.

[6] Yuan H. Educational Marketing of Customer Orientation. Beijing: Qinghua University Press, 2006. 
[7] Zhang Q. Marketing Research of Chinese University.Hefei: Chinese Science and Technolody Press, 2006.

[8] Zhang S. Marketing of Chinese Univeristy. Knowledge World, 23(2011)12-17.

[9] Gary, L. Marketing education. Berkshire: McGraw-Hall, 2008.

[10] Kotler P., Fox F. Strategic marketing for nonprofit organization. NJ: Prentice Hall, 2011. 